\title{
sciendo
}

\author{
Current Issues in Pharmacy and Medical Sciences
}

Formerly ANNALES UNIVERSITATIS MARIAE CURIE-SKIODOWSKA, SECTIO DDD, PHARMACIA

\section{Studies on perchlorate levels in powdered infant formulas available on the Polish market}

\author{
Przemyslaw Nizinski ${ }^{1 \star}$ ๑, Patrycja Wisniewska ${ }^{1}$, \\ Magdalena Kulinowska ${ }^{2}$, Anna BlazewiCZ ${ }^{1}$
}

${ }^{1}$ Chair of Chemistry, Department of Analytical Chemistry, Medical University of Lublin, Poland
${ }^{2}$ Student's Research Team in the Department of Analytical Chemistry, Medical University of Lublin, Poland

\section{ARTICLE INFO}

Received 25 March 2021

Accepted 10 May 2021

\section{Keywords:}

ion chromatography, endocrine disruptors, risk assessment, human health.

\begin{abstract}
Perchlorate has been acknowledged as a health threat due to its ability to interfere with iodine uptake by the thyroid gland. Infants and developing newborns have been considered as the most vulnerable groups to the perchlorate toxicity. A crucial source of perchlorate ingestion are powdered infant formulas. This study was designed to measure perchlorate content in thirty-one powdered infant formulas available on the Polish market. A rapid and sensitive ion chromatography method - conductivity cell detection - was applied to determine $\mathrm{ClO}_{4}^{-}$content. Limit of detection $(0.150 \mu \mathrm{g} / \mathrm{L})$ and limit of quantification $(0.450 \mu \mathrm{g} / \mathrm{L})$ were assessed. Collected samples were classified by the age of consumers: first stage, until the baby is six months old and follow-on formula for older children. Geometric mean of perchlorate concentration of $1.041 \mu \mathrm{g} / \mathrm{L}$ and $0.857 \mu \mathrm{g} / \mathrm{L}$ in the groups of the first stage and follow-on formulas were calculated, respectively. A health risk assessment revealed that the Tolerable Daily Intake (TDI) for perchlorate $(0.3 \mu \mathrm{g} / \mathrm{kg}$ body weight/day) was exceeded only in a few milk samples. The findings suggest that perchlorate contamination of powdered infant formulas may not to be an immediate health issue, yet testing for $\mathrm{ClO}_{4}^{-}$should continuously be conducted. To the best of our knowledge, this is the first study concerning perchlorate content in infant formulas in Poland.
\end{abstract}

\section{INTRODUCTION}

Perchlorate $\left(\mathrm{ClO}_{4}\right)$ is known as both a naturally occurring and man-made environmental contaminant. Natural sources of perchlorate are mostly related to the usage of Chilean nitrate fertilizers (which may be contaminated with $\mathrm{ClO}_{4}$ ) and to atmospheric formation [1]. Synthetic perchlorate is widely used as a propellant in rocket fuels, matches, fireworks, munitions, explosives and other pyrotechnic materials due to its very strong oxidizing properties [2]. Most of the commonly used perchlorate salts (i.e. ammonium perchlorate, sodium perchlorate) are well soluble in water. Owing to the fact that the perchlorate ion is a very poor complexing agent, it can be persistent in the environment for many years [3]. Perchlorate is known as one of the most potent endocrine disrupting chemicals (EDCs) [4]. Its mode of action is based on the disruption of the sodium/iodine symporter (NIS), which is a transmembrane protein that mediates iodide ions transport to the thyroid

\footnotetext{
* Corresponding author

e-mail: przemyslaw.nizinski@umlub.pl
}

cells [5]. Limited supply of the I- in the thyrocytes leads to insufficient production of thyroid hormones: triiodothyronine (T3) and thyroxine (T4), which could affect normal neurodevelopment, cognitive processes, metabolism and growth. Abnormal thyroid function caused by the perchlorate toxicity may lead to serious physical, as well as mental health issues [6]. A comprehensive review of the perchlorate properties, sources and toxicity to humans has been recently published elsewhere by the Authors [7].

Regulatory status of perchlorate seems to be controversial and uncertain. In 1998, perchlorate were placed on the Contaminate Candidate List 1 (CCL1) published by the United States Environmental Protection Agency (USEPA). This is a listing of potentially toxic compounds, for which further investigation is needed to establish safe level limitations [8]. In 2005, the National Research Council (NRC) established a perchlorate health advisory level - Reference Dose (RfD), based on the No Observed Adverse Effects Level (NOAEL) on $0.7 \mu \mathrm{g} / \mathrm{kg}$ body weight/day [9]. In 2015, the European Food Safety Agency (EFSA) Panel of Contaminants in the 
Food Chain (CONTAM) published a scientific opinion where Tolerable Daily Intake (TDI) level of perchlorate on $0.3 \mu \mathrm{g} / \mathrm{kg}$ body weight/day was proposed and then adopted by the European Commission as an advisory level [10]. The CONTAM Panel indicated newborns, infants and toddlers as the most vulnerable group to perchlorate acute toxicity [11]. Perchlorate can enter the human body via transdermal, inhalation and, most importantly, oral routes of exposure [7]. It was revealed that breast milk and powdered infant formulas (PIFs) are the most likely sources of perchlorate for newborns and infants [12]. With this in view, the European Commission published a 2020/85 Regulation that specifies maximum perchlorate level in PIFs at $10 \mu \mathrm{g} / \mathrm{kg}$ in 2020 , and recommended perchlorate monitoring in certain types of food [13].

The presence of perchlorate in infant formulas is, however, not well investigated. A study on perchlorate intake in infants from the USA was published in 2011. The report showed that neither children fed cow milk formula nor those fed soy-based formula exceeded the TDI level $(0.208 \mu \mathrm{g} / \mathrm{kg}$ body weight/day and $0.065 \mu \mathrm{g} / \mathrm{kg}$ body weight/day, respectively) [14]. To the best of our knowledge, only one study was conducted in Europe and it revealed that in some cases the health advisory level may be exceeded [15].

The primary purpose of the present study was to determine perchlorate levels in infant formulas available on the Polish market. Our main goals were to provide reliable data on perchlorate content in infant foods and to assess the possible health risk of perchlorate exposure to the subpopulation of newborns and infants. We employed conductivity cell detection (IC-CD) (a reliable and rapid method that is based on ion chromatography) to measure the content of perchlorate in the analyzed samples. We demonstrated that our method fulfils the requirements of the Commission Recommendation (EU) 2020/85 of perchlorate content in certain food products. To the best of our knowledge, this is the first attempt to investigate perchlorate occurrence in infant formulas in Poland.

\section{MATERIALS AND METHODS}

\section{Reagents and standards}

Perchlorate standard water solution $(996 \pm 6 \mathrm{mg} / \mathrm{L}$, certified reference material, CRM) was used (Sigma-Aldrich, St. Louis, MO, USA). Acetonitrile, methanol and ethanol were reagent-grade (Merck KGaA, Darmstadt, Germany). Sodium carbonate and sodium bicarbonate were of high purity - at least $99.5 \%$ (Merck KGaA, Darmstadt, Germany). Deionized water (DI water) with resistivity of $18.2 \mathrm{M} \Omega / \mathrm{cm}$ was obtained from a Direct-Q-3UVR water purification system (Merck KGaA, Darmstadt, Germany).

\section{Sample collection}

Thirty-one different brands of purchased infant formulas (PIFs) were purchased at local retail suppliers and pharmacy shops from January 2020 to March 2020. All of the purchased infant formulas were stored at room temperature until the first opening. Three general types of the PIFs were identified: bovine milk-based $(n=25)$, soy-based $(n=4)$, and elemental based on synthetic amino-acids $(n=2)$.

\section{Sample preparation}

Each sample of the collected PIFs was prepared according to general manufacturer's instructions. A sample preparation method previously described by Schier et al. in 2010, which was originally developed for LC-MS/MS determination was adopted [16]. However, in the absence of the expensive and complicated LC-MS/MS apparatus that was applied for the determination of perchlorate, the IC-CD technique was adopted. Importantly, this method was recognized as suitable for determination of perchlorate in powdered milk samples [17]. Nonetheless, some modifications aiming at adjusting the procedure for IC-CD analysis were introduced. In order to prepare the samples, $5 \mathrm{~g}$ of infant formula was dissolved in a volume of $30 \mathrm{~mL}$ using perchlorate free DI water at temperature of $40^{\circ} \mathrm{C}$ and vortex mixed for 1 minute. $5 \mathrm{~mL}$ of the reconstituted PIF was then transferred to the $15 \mathrm{~mL}$ polypropylene (PP) tube and $5 \mathrm{~mL}$ of cold ethanol $\left(-25^{\circ} \mathrm{C}\right)$ was added in order to precipitate the proteins. The obtained mixture was stored in a refrigerator at $-25^{\circ} \mathrm{C}$ for twelve hours. Next, the mixture was centrifuged at 5000 RPM for 30 minutes at room temperature and the supernatant was collected. The supernatant was dried under a stream of nitrogen gas and the remaining residue was dissolved in $1 \mathrm{~mL}$ of DI water. The obtained solution underwent a solid phase extraction (SPE) cleanup procedure.

\section{Solid phase extraction}

C-18 Clean-UP ${ }^{\circledR}$ CEC-181M6 SPE 6 mL end-capped cartridges (UCT, Bristol, PA) were used in the extraction protocol. The cartridges were characterized by the following parameters: sorbent mass: $1000 \mathrm{mg}$, having $21.5 \% \mathrm{C}$ and surface area $500 \mathrm{~m}^{2} / \mathrm{g}$, average pore size $60 \AA$ and pore volume $0.77 \mathrm{~cm}^{3} / \mathrm{g}$. Two SPE columns were connected on-line, and pre-conditioned using $1 \mathrm{~mL}$ of DI water. Subsequently, $1 \mathrm{~mL}$ of the previously obtained sample was transferred to the cartridge, then $1 \mathrm{~mL}$ of DI water was used as a wash. The eluate was collected to the PP tube, diluted to the original volume of $5 \mathrm{~mL}$ and vortexed for 5 minutes. The acquired solution was transferred to the $10 \mathrm{~mL}$ PP autosampler vial and placed in the autosampler until ion chromatography analysis.

\section{Ion chromatography analysis}

An ion chromatograph 930 Compact IC Flex (Metrohm AG, Herisau, Switzerland) with isocratic pump, MSM-HC suppressor, conductivity cell detector and 919 IC Autosampler were used to perform perchlorate determination in the PIFs samples. The calibration was performed in compliance with ISO 8466-1 guidelines [18]. Six standard solutions were prepared using a dilution of CRM to $1.5,3,5,7.5,10$ and $15 \mu \mathrm{g} / \mathrm{L}$. Each standard underwent chromatographical analysis three times. The calibration curve of the perchlorate standard solutions is presented in Figure 1. Obtained results served to estimate the following parameters: limit of detection (LOD), limit of quantification (LOQ), standard deviation (SD), relative standard deviation (RSD) and regression coefficient (Table 1). 
Table 1. Validation parameters of the analytical method

\begin{tabular}{|l|c|}
\hline \multicolumn{1}{|c|}{ Parameter } & Value \\
\hline Concentration range $(\mu \mathrm{g} / \mathrm{L})$ & $1.500-15.000$ \\
\hline Standard deviation $(\mathrm{SD})(\mu \mathrm{g} / \mathrm{L})$ & 0.045 \\
\hline Relative standard deviation (RSD) $(\%)$ & 0.781 \\
\hline Limit of detection $(\mathrm{LOD})(\mu \mathrm{g} / \mathrm{L})$ & 0.150 \\
\hline Limit of quantification $(\mathrm{LOQ})(\mu \mathrm{g} / \mathrm{L})$ & 0.450 \\
\hline Regression coefficient $\mathrm{r}^{2}$ & 0.9999 \\
\hline Recovery $(\%)$ & 96 \\
\hline
\end{tabular}

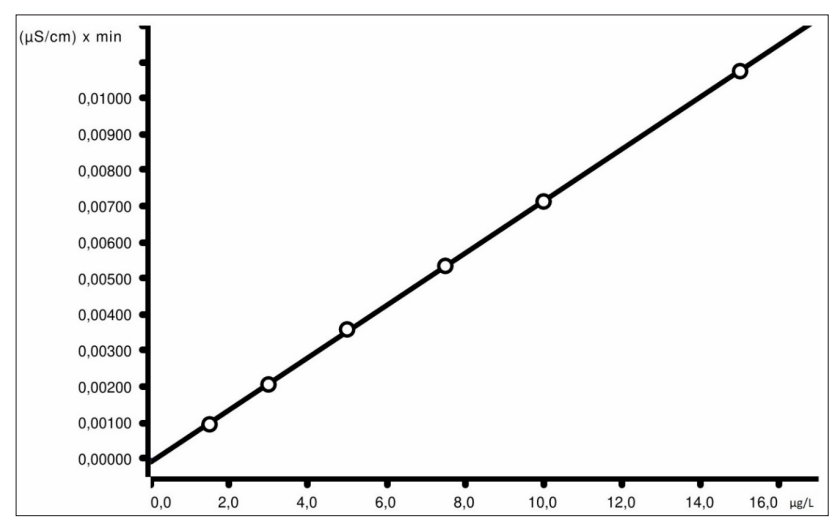

Figure 1. Perchlorate calibration curve

Methodology of LOD and LOQ assessment was based on Approach 1 (described elsewhere) [19]. LOD and LOQ were estimated using calculations based on 3.3 or 10 times standard deviation of the lower concentration as obtained from standard curve, respectively. For the linear range, concentrations from LOD to $15 \mu \mathrm{g} / \mathrm{L}$ were selected. PIFs samples that contain perchlorate beyond the calibration range were properly diluted and they were then analyzed again. The correlation coefficient $\left(r^{2}\right)$ obtained from linear regression analysis was calculated, and the obtained result of 0.9999 represents a good linearity within this range and effective quantification of the method.

For SPE accuracy, sample cleanup method evaluation through recovery studies was performed. Due to the lack of availability of certified reference material (CRM) of perchlorate in PIFs, the recovery tests were conducted by using fortified samples. Test sample was spiked with 5, 10 and $15 \mu \mathrm{g} / \mathrm{L}$ perchlorate and then underwent SPE protocol. Three replicates of each standard were analyzed, and the mean

Table 2. Analytical conditions

\begin{tabular}{|l|c|}
\hline \multicolumn{1}{|c|}{ Apparatus } & Metrohm 930 Compact IC Flex \\
\hline Column & Metrosep A Supp 5 $150.0 \times 4.0 \mathrm{~mm}$ \\
\hline Pre-column & Metrosep A Supp $4 / 5$ Guard $50.0 \times 4.0 \mathrm{~mm}$ \\
\hline Eluent flow rate & $0.5 \mathrm{~mL} / \mathrm{min}$ \\
\hline Eluent composition & $\begin{array}{c}7 \mathrm{mM} \text { sodium bicarbonate }+2 \mathrm{mM} \text { sodium } \\
\text { carbonate }+25 \% \text { acetonitrile }\end{array}$ \\
\hline Column temperature & $25{ }^{\circ} \mathrm{C}$ \\
\hline Sample volume & $250 \mathrm{~L}$ \\
\hline Expected backpressure & $\sim 14 \mathrm{MPa}$ \\
\hline Run time & 30.00 minutes \\
\hline Perchlorate retention time & 21.45 minutes \\
\hline
\end{tabular}

recovery was $96 \%$. The calibration verification standard $(5 \mu \mathrm{g} / \mathrm{L})$ was analyzed every 5 samples in order to demonstrate that the equipment was properly settled during the analysis. Moreover, a sample of DI water was injected before each new sample to verify that the obtained results of perchlorate concentration were not an artefact. Each sample was injected into the system three times. Analytical conditions and calibration parameters are given in Table 2.

\section{Data analysis}

MagicIC Net 3.2 Software (Metrohm AG, Herisau, Switzerland) was employed to operate the apparatus, collect and integrate the results of the IC analysis. Statistica 13 (Tibco Inc, Palo Alto, CA, USA) was applied to perform statistical tests. Basic descriptive statistics were presented. Mann-Whitney U test was calculated in order to compare the groups of first stage and follow-on formulas. The content of perchlorate in the dry mass of PIFs samples was calculated as follows: measured perchlorate concentration (i.e. average of triplicate) was multiplied by originally prepared volume of each PIF sample $(0.03 \mathrm{~L})$ which was then divided by the mass of each PIF sample $(0.005 \mathrm{~kg})$. The abovementioned equation is presented below: $\begin{gathered}\text { Perchlorate content } \\ (\mu \mathrm{g} / \mathrm{kg})\end{gathered}$
Perchlorate concentration $(\mu \mathrm{g} / \mathrm{L}) \times$ original PIF volume $(L)$

${ }^{1}$ The volume of the sample obtained after the preparation process equaled to the volume taken for preparation, thus it was omitted in the calculations Equation 1. Calculation of perchlorate content in PIFs dry weight ${ }^{1}$

\section{RESULTS}

Among thirty-one collected and analyzed powdered infant formula samples, merely twenty-two, which constitute $66.66 \%$ of the tested samples, indicated detectable content of perchlorate. In such samples, the signal in chromatographic analysis was adequate to reliably calculate perchlorate concentration. A chromatogram of real sample against the background of DI water and standard solution is presented in Figure 2. The geometric mean of perchlorate content and perchlorate concentration range in analyzed samples are shown in Table 3.

Table 3. Perchlorate content in PIFs samples

\begin{tabular}{|c|c|c|c|c|c|c|c|}
\hline 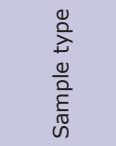 & 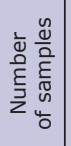 & 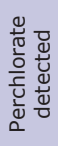 & 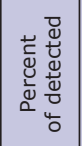 & $\sum_{0} \frac{1}{\frac{1}{0 t}}$ & 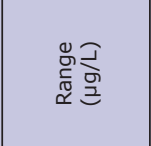 & 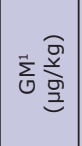 & 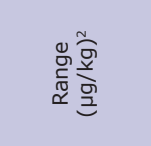 \\
\hline $\begin{array}{l}\text { Milk- } \\
\text { based }\end{array}$ & 25 & 18 & $72 \%$ & 0.993 & $0.494-5.063$ & 5.960 & $2.967-30.380$ \\
\hline $\begin{array}{l}\text { Soy- } \\
\text { based }\end{array}$ & 4 & 2 & $50 \%$ & 0.954 & $0.520-1.749$ & 5.724 & $3.120-10.494$ \\
\hline Elemental & 2 & 2 & $100 \%$ & 0.654 & $0.499-0.857$ & 3.925 & $2.997-5.142$ \\
\hline
\end{tabular}

So as to perform the health risk assessment of perchlorate intake, the following samples were classified according to the age of the consumers: first stage infant formulas - up to six months of age, and follow-on formulas - for older children. The calculations for those groups are presented in Table 4. 


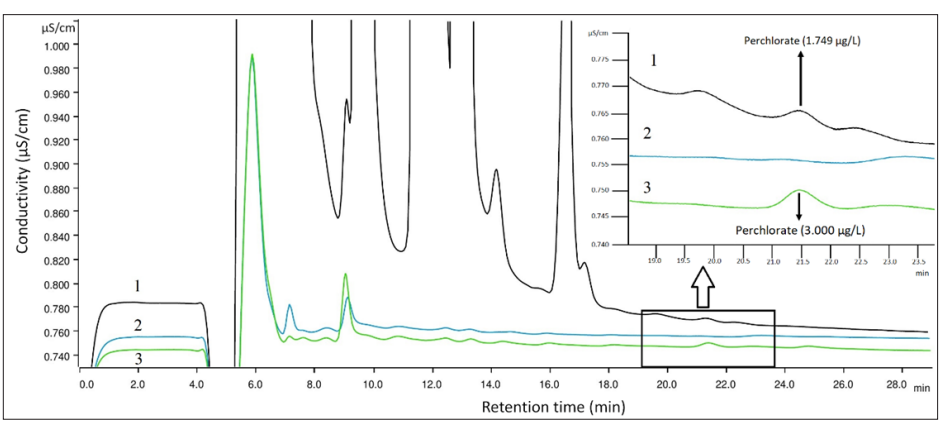

Figure 2. Chromatogram demonstrating perchlorate concentration in infant formula sample (1), DI water (2) and standard solution (3)

Table 4. Perchlorate content in first stage and follow-on infant formulas

\begin{tabular}{|c|c|c|c|c|c|c|c|}
\hline 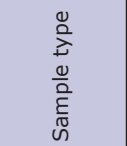 & 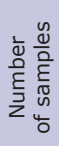 & 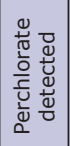 & 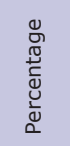 & 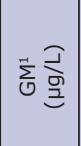 &  & 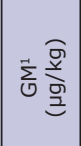 & 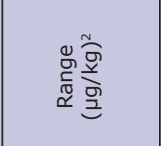 \\
\hline First stage & 16 & 12 & $75 \%$ & 1.041 & $0.499-4.588$ & 6.246 & $2.997-27.528$ \\
\hline Follow-on & 15 & 10 & $66 \%$ & 0.857 & $0.494-5.060$ & 5.142 & $2.967-30.380$ \\
\hline
\end{tabular}

The performed statistical analysis (Mann-Whitney U test, data not shown) revealed that there are no statistically significant differences between perchlorate content in the first stage PIFs and follow-on PIFs ( $p>0.05$ ). Most samples $(n=28)$ after reconstitution had perchlorate content below $1.667 \mu \mathrm{g} / \mathrm{L}$ - which corresponds to the maximum permissible level in powdered formulas set at $10 \mu \mathrm{g} / \mathrm{kg}$ (see Equation 1). The obtained results were calculated to the PIFs dry weight.

The maximum acceptable level was exceeded in the case of four samples. Three of these were first stage PIFs. Here the perchlorate levels were $15.387 \pm 0.362 \mu \mathrm{g} / \mathrm{kg}$, $27.528 \pm 1.074 \mu \mathrm{g} / \mathrm{kg}$ and $10.494 \pm 0.016 \mu \mathrm{g} / \mathrm{kg}$ (mean $\pm \mathrm{SD}$ ). Only one sample was a follow-on PIF. Here, the perchlorate content was $30.380 \pm 0.485 \mu \mathrm{g} / \mathrm{kg}$ (mean $\pm \mathrm{SD}$ ). The mentioned samples represented $19 \%$ and $7 \%$ of all studied samples in each group, respectively (see Figure 3).

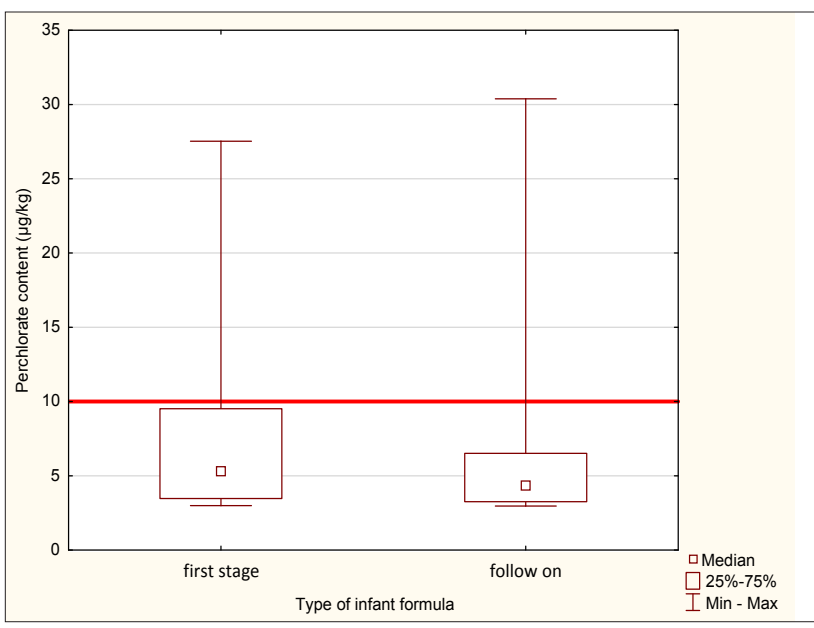

Figure 3. Perchlorate content in the first stage and the follow-on PIFs. The red line corresponds to the maximum permissible level of perchlorate in the PIFs $(10 \mu \mathrm{g} / \mathrm{kg}$ of PIF dry weight)
Exposure to perchlorate from PIFs intake of newborns and infants was calculated by using the data from children's energy requirements as established by the Food and Agriculture Organization (FAO) [20]. The average energy content in the studied samples of PIFs was estimated at $275 \mathrm{~kJ} / 100 \mathrm{~mL}$ of reconstituted formula according to manufacturers` information.

The approximate consumption of infant formulas was estimated by multiplying the median weight of children of a given age by the daily energy requirement per kilogram of body weight. This figure was then divided by the average energy value per $100 \mathrm{~mL}$ of PIFs. See Equation 2 below.

$\begin{gathered}\text { Perchlorate content } \\ (\mu \mathrm{g} / \mathrm{kg})\end{gathered} \quad=\frac{\text { perchlorate concentration }(\mu \mathrm{g} / \mathrm{L}) \times \text { original PIF volume }(L)}{\text { PIF sample weight }(\mathrm{kg})}$

Equation 2. Calculation of daily PIF intake

The obtained data was used to estimate the daily consumption of perchlorate. It was assumed that children are fed only on infant formulas, and the water used to prepare the solution is perchlorate-free. The weight of girls and boys was averaged. Exposure estimation was performed taking into account the geometric mean of $\mathrm{ClO}_{4}^{-}$concentration and the highest concentration values both in the first-stage groups (i.e. 1 month and 6 month) and follow-on formulas (i.e. 12 month and 24 month) groups. The results are given in Table 5.

Table 5. Risk assessment for perchlorate intake of children aged 1-24 months, drinking solely infant formulas.

\begin{tabular}{|c|c|c|c|c|c|c|c|}
\hline 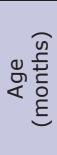 & $\begin{array}{l}\frac{n}{5} \\
\frac{0}{0} \\
3 \\
3 \\
\text { वे } \\
0 \\
0\end{array}$ & 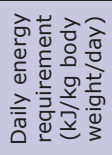 & 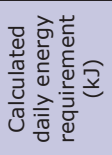 & 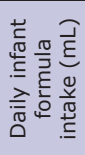 & \multicolumn{2}{|c|}{ 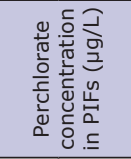 } & 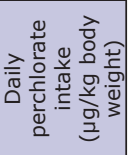 \\
\hline \multirow{2}{*}{1} & \multirow{2}{*}{4.35} & \multirow{2}{*}{485} & \multirow{2}{*}{2110} & \multirow{2}{*}{767} & GM & 1.041 & 0.184 \\
\hline & & & & & Max & 4.588 & 0.809 \\
\hline \multirow{2}{*}{6} & \multirow{2}{*}{7.60} & \multirow{2}{*}{349} & \multirow{2}{*}{2652} & \multirow{2}{*}{965} & GM & 1.041 & 0.132 \\
\hline & & & & & Max & 4.588 & 0.583 \\
\hline \multirow{2}{*}{12} & \multirow{2}{*}{9.25} & \multirow{2}{*}{343} & \multirow{2}{*}{3173} & \multirow{2}{*}{1154} & GM & 0.857 & 0.107 \\
\hline & & & & & Max & 5.060 & 0.631 \\
\hline \multirow{2}{*}{24} & \multirow{2}{*}{11.85} & \multirow{2}{*}{345} & \multirow{2}{*}{4088} & \multirow{2}{*}{1487} & GM & 0.857 & 0.108 \\
\hline & & & & & Max & 5.060 & 0.635 \\
\hline
\end{tabular}

Abbreviations: GM - geometric mean of perchlorate content, Max - maximum reported concentration. Bold values indicate that TDI level $(0.3 \mu \mathrm{g} / \mathrm{kg})$ [10] of daily perchlorate intake is exceeded

${ }^{1}$ Female and male body weighs were averaged. The values were obtained from the WHO data [21]

2 Daily energy requirement data was obtained from FAO recommendations [20]

\section{DISCUSSION}

\section{Presence of perchlorate in powdered infant formulas and health risk assessment}

Over the years, several studies have been published on the presence of perchlorate in PIFs. Importantly, in order to find relevant articles concerning the determination of perchlorate in infant formulas, such databases as Scopus and PubMed were thoroughly investigated. The collected results are presented in Table 6. 
Table 6. Worldwide occurrence of perchlorate in infant formulas

\begin{tabular}{|c|c|c|c|c|c|}
\hline $\begin{array}{l}\text { Type/form of the } \\
\text { infant formula }\end{array}$ & \begin{tabular}{|l|} 
Country \\
of origin
\end{tabular} & $\begin{array}{c}\text { Number of } \\
\text { samples }\end{array}$ & \begin{tabular}{|c|} 
Perchlorate \\
concentration \\
\end{tabular} & Remarks & References \\
\hline liquid & USA & 17 & $0.2-4.1 \mu \mathrm{g} / \mathrm{L}$ & $\mathrm{NA}^{1}$ & [22] \\
\hline $\begin{array}{l}\text { powdered, } \\
\text { milk-based }\end{array}$ & \multirow{4}{*}{ USA } & 15 & $1.72 \mu \mathrm{g} / \mathrm{L}$ & \multirow{4}{*}{$\begin{array}{l}\text { measured after } \\
\text { reconstitution }\end{array}$} & \multirow{4}{*}{ [16] } \\
\hline $\begin{array}{l}\text { powdered, } \\
\text { soy-based }\end{array}$ & & 15 & $0.21 \mu \mathrm{g} / \mathrm{L}$ & & \\
\hline $\begin{array}{l}\text { powdered, } \\
\text { milk-based, } \\
\text { lactose-free }\end{array}$ & & 9 & $0.27 \mu \mathrm{g} / \mathrm{L}$ & & \\
\hline $\begin{array}{l}\text { powdered, } \\
\text { elemental }\end{array}$ & & 6 & $0.18 \mu \mathrm{g} / \mathrm{L}$ & & \\
\hline $\begin{array}{l}\text { powdered, } \\
\text { milk-based }\end{array}$ & $\begin{array}{l}\text { Rep. of } \\
\text { Korea }\end{array}$ & 26 & $\begin{array}{c}1.49-33.33 \\
\mu \mathrm{g} / \mathrm{kg}\end{array}$ & $\begin{array}{l}\text { no data after } \\
\text { reconstitution } \\
\text { provided }\end{array}$ & [23] \\
\hline $\begin{array}{l}\text { powdered, } \\
\text { milk-based }\end{array}$ & \multirow[t]{2}{*}{ Canada } & 19 & $\begin{array}{c}0.21-13.5 \\
\mu \mathrm{g} / \mathrm{L}\end{array}$ & $\begin{array}{c}\text { measured after } \\
\text { reconstitution, } \\
18 \text { samples were } \\
\text { above LOD² }\end{array}$ & \multirow[t]{2}{*}{ [24] } \\
\hline liquid, milk-based & & 20 & $\begin{array}{c}0.37-3.56 \\
\mu \mathrm{g} / \mathrm{L}\end{array}$ & $\mathrm{NA}^{1}$ & \\
\hline powdered & $\begin{array}{l}\text { Rep. of } \\
\text { Korea }\end{array}$ & 5 & $\begin{array}{c}5.21-22.60 \\
\mu \mathrm{g} / \mathrm{kg}\end{array}$ & $\begin{array}{l}\text { no data after } \\
\text { reconstitution } \\
\text { provided }\end{array}$ & [25] \\
\hline powdered & France & 67 & $2.0-12.8 \mu \mathrm{g} / \mathrm{L}$ & $\begin{array}{c}\text { measured after } \\
\text { reconstitution, } \\
\begin{array}{c}32 \text { samples were } \\
\text { above LOD² }\end{array}\end{array}$ & [15] \\
\hline milk-based & \multirow{5}{*}{ USA } & 4 & $2.0-2.5 \mu \mathrm{g} / \mathrm{L}$ & $\begin{array}{c}\text { form of formula } \\
\text { not specified, } \\
\text { high-iron } \\
\text { level indicated }\end{array}$ & \multirow{3}{*}{ [26] } \\
\hline milk-based & & 4 & $1.2-3.6 \mu \mathrm{g} / \mathrm{L}$ & \begin{tabular}{|c|} 
form of formula \\
not specified, \\
low-iron \\
level indicated
\end{tabular} & \\
\hline soy-based & & 4 & $0.8 \mu \mathrm{g} / \mathrm{L}$ & $\begin{array}{c}\text { form of formula } \\
\text { not specified }\end{array}$ & \\
\hline liquid, milk-based & & 20 & $1.0-3.0 \mu \mathrm{g} / \mathrm{L}$ & $\begin{array}{c}\text { high-iron level } \\
\text { indicated }\end{array}$ & \multirow{2}{*}[27]{} \\
\hline liquid, soy-based & & 20 & $2.0-5.0 \mu \mathrm{g} / \mathrm{L}$ & $\begin{array}{l}\text { not detected } \\
\text { in } 9 \text { samples }\end{array}$ & \\
\hline no data & Kuwait & 10 & $8.1 \mu \mathrm{g} / \mathrm{L}$ & $\begin{array}{c}\text { form } \\
\text { not specified }\end{array}$ & {$[28]$} \\
\hline
\end{tabular}

The obtained results of perchlorate content in milk-based formulas (range 2.967-30.380 $\mu \mathrm{g} / \mathrm{kg}$ ) seem to be consistent with the results of studies conducted by Her et al. 2010 [23] and Lee et al. 2012 [25]. Here, high levels of $\mathrm{ClO}_{4}^{-}$(max $33.33 \mu \mathrm{g} / \mathrm{kg}$ and $22.60 \mu \mathrm{g} / \mathrm{kg}$ of the dry weight of PIFs, respectively) were determined in several samples [23,25]. Notably, elevated content (over $10 \mu \mathrm{g} / \mathrm{kg}$ of dry weight) was determined only in the case of four samples.

The obtained results in the present study (range 0.494$5.063 \mu \mathrm{g} / \mathrm{L}$ ) seem to be inconsiderably lower than the values reported by Vigreux-Baset et al. in 2015 (range 2.0-12.8 $\mu \mathrm{g} / \mathrm{L})$ [15]. It should be noted that in the study carried out by Vigreux-Baset et al. in 2015 [15], only $48 \%$ of the tested samples indicated concentrations above the limit of quantification $(2 \mu \mathrm{g} / \mathrm{L})$, whereas in our work it is over $66 \%$. This may result from the lower limit of quantification of the method $(0.450 \mu \mathrm{g} / \mathrm{L})$ that was employed in the present research. Apart from the abovementioned studies by Her et al. 2010 [23] and Lee et al. 2012 [25] from the Republic of Korea, higher perchlorate concentrations were also detected by Alomirah et al. 2016 [28] in Kuwait, where the average concentration of $\mathrm{ClO}_{4}^{-}$in the studied PIFs samples was $8.1 \mu \mathrm{g} / \mathrm{L}$. Nonetheless, drawing further conclusions has high risk of bias owing to the limited sample population.

Our risk assessment showed that the TDI for perchlorate can be significantly exceeded in some cases. Nevertheless, the analysis indicated that there is a risk of exposure to excessive doses of perchlorate only in the case of PIFs with the highest $\mathrm{ClO}_{4}^{-}$content. As long as the geometric mean value is used for the calculations, the Tolerable Daily Intake value $(0.3 \mu \mathrm{g} / \mathrm{kg}$ body weight/day $)$ is not exceeded. However, the amount of perchlorate in drinking water, which is used to prepare meals based on powdered infant formulas, should not be underestimated. Recent studies from France indicate that in some areas, in particular those with some military operations or with military ammunition depots, perchlorate contamination of surface and groundwater may be significant [29]. Some studies have estimated the cumulative exposure to perchlorate found in PIFs and in drinking water.

Some studies propose to theoretically calculate perchlorate concentration in water in combination with the $\mathrm{ClO}_{4}^{-}$content in infant formulas, which results in exceeding the RfD. The research by Schier et al. in 2010 [16] reported the range of concentrations of perchlorate in water at $1.77-6.30 \mu \mathrm{g} / \mathrm{L}$, hence it is highly probable that the daily tolerated dose is exceeded. A similar estimation can be found in the work of Vigreux-Besret et al. 2015 [15], where the perchlorate concentration in water of $4 \mu \mathrm{g} / \mathrm{L}$ was used for the calculations. In this study, $5 \%$ of the most exposed children exceeded the safety limit [15]. Importantly, in both of these studies, the reference value amounted to $0.7 \mu \mathrm{g} / \mathrm{kg}$ body weight/ day. The current standard was tightened to $0.3 \mu \mathrm{g} / \mathrm{kg}$ body weight/day [10].

Fruit and vegetables containing significant amounts of $\mathrm{ClO}_{4}^{-}$may also be an important source of perchlorate exposure, especially among older children. Indeed, research indicates that over $50 \%$ of all perchlorate exposure comes from these products [30]. It seems justified to conduct research on the determination of perchlorate in fruit and vegetables. The data on the results of these analyzes have not been publicized despite the monitoring recommendation introduced by the European Commission. The content of perchlorate in food products other than infant formulas was not determined in the present study, but the issue is to be addressed in the near future.

\section{Iodine supply and perchlorate ingestion}

According to available data, the population of Poland runs the risk of iodine deficiencies [31]. The most vulnerable groups include, but are not limited to, newborns and infants, due to the prompt developmental processes and high caloric demand in the early stages of life [10]. Under conditions of inadequate iodine intake in the diet, the effects of perchlorate exposure may be more severe [6]. Recently published studies on the supply of iodine in children in Poland indicate that children fed on mother's milk are much more exposed to deficiencies when compared to those consuming only infant formulas [31]. However, it is not clear how perchlorate in concentrations present in PIFs may affect thyroid function in children. Recent studies seem to indicate that perchlorate may interrupt iodine uptake by the thyroid gland in much lower concentrations than previously thought [5]. The applicable standards and recommendations were developed before the publication of the results of these studies [11]. Previous studies revealed that in the case of autism spectrum 
disorders (ASD), the iodine level in children aged ranging between 2-17 is significantly lower compared to healthy volunteers [32]. Bearing in mind the latest discoveries, as well as insufficient information provided on the supply of iodine in the diet, conducting similar studies in the group of the youngest children seems to be highly justified.

\section{Analytical issues}

The IC-CD technique was successfully used to determine the concentration of perchlorate in PIFs, and the method developed in the present article allows for rapid, selective and sensitive determination of perchlorate content. Although methods based on mass spectrometry detection are characterized by lower detection limits [3], they require more expensive equipment. The European Commission for the determination of perchlorate in food mentions the Quick Polar Pesticides Method (QuPPe) 7.1 method, the detection limit for perchlorate of which was calculated at $0.05 \mu \mathrm{g} / \mathrm{L}$ [34], while maximum permissible level of perchlorate in PIFs was set at $10 \mu \mathrm{g} / \mathrm{kg}(1.667 \mu \mathrm{g} / \mathrm{L}$ in the reconstituted formula) [13]. An IC-CD technique employed in this study is characterized by sufficient sensitivity and selectivity in perchlorate determination in PIFs samples. The method used here, together with the described sample preparation procedure, allows achieving a LOQ of $0.450 \mu \mathrm{g} / \mathrm{L}$ in the reconstituted infant formulas $(2.70 \mu \mathrm{g} / \mathrm{kg}$ in terms of PIFs dry weight), thus it meets the requirements of the regulator [13]. To the best of our knowledge, this is the first attempt to assess the health risk of perchlorate exposure from infant formulas in Poland.

\section{Limitations of the study}

The method presented in this article is characterized by a low quantification limit $(0.450 \mu \mathrm{g} / \mathrm{L})$, which is satisfactory for the determination of perchlorate at the currently recommended levels in infant formulas. However, if the acceptable standards are tightened, the sensitivity of the determination may turn out to be insufficient. The research was limited to one production batch of a given PIF brand, and only 31 brands of PIFs were analyzed, hence the results may not fully reflect the actual state of affairs. There are other brands of PIFs available on the Polish market, and perchlorate content remains unknown in those formulas. The health risk analysis is based on the values of children's body weight and daily energy requirements provided by WHO and FAO, which may differ to some extent from the actual state in Poland. Research covering a sufficiently large group of children in Poland may provide relevant information on the exposure of this sub-population to perchlorate. Such studies have been conducted, for example, in France [15]; however, doing so requires the interdisciplinary cooperation of many research and clinical centers.

\section{CONCLUSION}

The analysis of PIFs samples available on the Polish market showed a low contamination of these products with perchlorate, however, in the case of four samples, the $\mathrm{ClO}_{4}^{-}$ content is significant. The performed health risk analysis demonstrates that consumption of infant formulas containing an average determined amount of perchlorate does not pose a significant health risk, as the level of $0.3 \mu \mathrm{g} / \mathrm{kg}$ body weight/ day is not exceeded. Acquired data has shown that perchlorate exposure from PIFs intake seems not to be an immediate health issue. Nevertheless, a significant excess of the TDI was found in children who consume infant formulas with the highest determined concentrations of $\mathrm{ClO}_{4}^{-}$. This may pose a considerable risk of diseases related to thyroid disruption. The method presented in the course of the article based on IC-CD allowed for quick and reliable determination of perchlorate in the tested samples. The obtained detection and quantification limits fully comply with the applicable recommendations in the European Union.

\section{ACKNOWLEDGEMENTS}

\section{FINANCIAL SUPPORT AND SPONSORSHIP}

This research was funded by Medical University of Lublin (Funding No 53/2020).

\section{CONFLICTS OF INTERESTS}

The Authors declare no conflict of interests.

\section{ETHICAL APPROVAL}

Not applicable.

\section{ORCID iDs}

Przemysław Niziński (Dhttps://orcid.org/0000-0003-1724-0089

\section{REFERNCES}

1. Kumarathilaka P, Oze C, Indraratne SP, Vithanage M. Perchlorate as an emerging contaminant in soil, water and food. Chemosphere. 2016;150:667-77.

2. Agency for Toxic Substances and Disease Registry. Toxicological Profile for Perchlorates. Atlanta: GA, USA: US Department of Health and Human Services; 2008:1-13.

3. Gu B, Coates JD. Perchlorate: Environmental occurrence, interactions and treatment. Perchlorate: Environmental Occurrence, Interactions and Treatment. Boston, MA, USA: Springer; 2006:1-411.

4. Wolff J. Perchlorate and the Thyroid Gland. Pharmacol Rev. 1998; 50(1):89-105.

5. Llorente-Esteban A, Manville RW, Reyna-Neyra A, Abbott GW, Amzel LM, Carrasco N. Allosteric regulation of mammalian $\mathrm{Na}^{+} /$ $\mathrm{I}^{-}$symporter activity by perchlorate. Nat Struct Mol Biol. 2020; 27(6):533-9.

6. Soldin OP, Braverman LE, Lamm SH. Perchlorate Clinical Pharmacology and Human Health: A review. Ther Drug Monit. 2001;23(4):316-31.

7. Niziński P, Błażewicz A, Kończyk J, Michalski R. Perchlorate properties, toxicity and human health effects: an updated review. Rev Environ Health. 2020;0(0). (Ahead of print).

8. US Environmental Protection Agency. Contaminant Drinking Water: Final Action on Perchlorate. A Rule by the Environmental Protection Agency on 07/21/2020. 85 FR 43990. Washington, DC, USA: EPA; 2020. Available from: https://www.govinfo.gov/content/pkg/ FR-2020-07-21/pdf/2020-13462.pdf (Accessed on 20 March 2021).

9. US Environmental Protection Agency. 2018 Edition of the Drinking Water Standards and Health Advisories Tables. Washington, DC, USA: EPA; 2018. Available from: https://www.epa.gov/sites/ production/files/2018-03/documents/dwtable2018.pdf (Accessed on 20 March 2021).

10. European Food Safety Authority CONTAM Panel. Scientific Opinion on the risks to public health related to the presence of perchlorate in food, in particular fruits and vegetables. EFSA J. 2014;12(10). 
11. European Commission. COMMISSION RECOMMENDATION (EU) 2015/682 of 29 April 2015 on the monitoring of the presence of perchlorate in food. Brussels, Belgium; 2015. Available from: https:// eur-lex.europa.eu/legal-content/EN/TXT/HTML/?uri=CELEX:320 $15 \mathrm{H} 0682 \&$ from=EN (Accessed on 20 March 2021).

12. Lisco G, De Tullio A, Giagulli VA, De Pergola G, Triggiani V. Interference on iodine uptake and human thyroid function by perchlorate-contaminated water and food. Nutrients. 2020;12(6):1-17.

13. European Commission. COMMISSION REGULATION (EU) 2020/685 of 20 May 2020 amending Regulation (EC) No 1881/2006 as regards maximum levels of perchlorate in certain foods. Brussels, Belgium; 2020. Available from: https://eur-lex.europa.eu/legal-content/EN/ TXT/HTML/?uri=CELEX:32020R0685\&from=EN (Accessed on 20 March 2021).

14. Valentín-Blasini L, Blount BC, Otero-Santos SM, Cao Y, Bernbaum JC, Rogan WJ. Perchlorate exposure and dose estimates in infants. Environ Sci Technol. 2011;45(9):4127-32.

15. Vigreux-Besret C, Mahé A, Ledoux G, Garnier A, Rosin C, Baert A, et al. Perchlorate: water and infant formulae contamination in France and risk assessment in infants. Food Addit Contam - Part A Chem Anal Control Expo Risk Assess. 2015; 32(7):1148-55.

16. Schier JG, Wolkin AF, Valentin-Blasini L, Belson MG, Kieszak SM, Rubin CS, et al. Perchlorate exposure from infant formula and comparisons with the perchlorate reference dose. J Expo Sci Environ Epidemiol. 2010;20(3):281-7.

17. Kirk AB, Smith EE, Tian K, Anderson TA, Dasgupta PK. Perchlorate in Milk. Environ Sci Technol. 2003;37(21):4979-81.

18. International Organization for Standardization. ISO 8466-1:1990. Geneva, Switzerland: ISO; 1990.

19. Ivanova V, Surleva A, Koleva B. Validation of Ion Chromatographic Method for Determination of Standard Inorganic Anions in Treated and Untreated Drinking Water. IOP Conf Ser Mater Sci Eng. 2018;374(1)

20. Food and Agriculture Organization. Energy and protein requirements. Geneva, Switzerland: FAO; 1985. Available from: http://www.fao. org/3/aa040e/aa040e00.htm (Accessed on 20 March 2021).

21. World Health Organization. Child growth standards. Geneva, Switzerland: WHO; 2021 Available from: https://www.who.int/ tools/child-growth-standards/standards/weight-for-age (Accessed on 20 March 2021).

22. Pearce EN, Leung AM, Blount BC, Bazrafshan HR, He X, Pino S, et al. Breast milk iodine and perchlorate concentrations in lactating Boston-area women. J Clin Endocrinol Metab. 2007;92(5):1673-7.

23. Her N, Kim J, Yoon Y. Perchlorate in dairy milk and milkbased powdered infant formula in South Korea. Chemosphere. 2010;81(6):732-7.
24. Wang Z, Sparling M, Tague B. Analysis of perchlorate in baby food on Canadian (Ottawa) markets in 2009 and estimated dietary exposure. Food Addit Contam - Part A Chem Anal Control Expo Risk Assess. 2018;35(10):2022-31.

25. Lee J-W, Oh S-H, Oh J-E. Monitoring of perchlorate in diverse foods and its estimated dietary exposure for Korea populations. J Hazard Mater. 2012;243:52-8.

26. Murray CW, Egan SK, Kim H, Beru N, Bolger PM. US food and drug administration's total diet study: Dietary intake of perchlorate and iodine. J Expo Sci Environ Epidemiol. 2008;18(6):571-80.

27. Abt E, Spungen J, Pouillot R, Gamalo-Siebers M, Wirtz M. Update on dietary intake of perchlorate and iodine from U.S. food and drug administration's total diet study: 2008-2012. J Expo Sci Environ Epidemiol. 2018;28(1):21-30.

28. Alomirah HF, Al-Zenki SF, Alaswad MC, Alruwaih NA, Wu Q, Kannan K. Widespread occurrence of perchlorate in water, foodstuffs and human urine collected from Kuwait and its contribution to human exposure. Food Addit Contam - Part A Chem Anal Control Expo Risk Assess. 2016;33(6):1016-25.

29. Cao F, Jaunat J, Ollivier P, Cancès B, Morvan X, Hubé D, et al. Sources and behavior of perchlorate ions $\left(\mathrm{ClO}_{4}\right)$ in chalk aquifer of Champagne-Ardenne, France: Preliminary results. Proc Int Assoc Hydrol Sci. 2018;379:113-7.

30. Calderon R, Godoy F, Escudey M, Palma P. A review of perchlorate $\left(\mathrm{ClO}_{4}\right)$ occurrence in fruits and vegetables. Environ Monit Assess. 2017;189(2).

31. Halczuk KM, Karwowski BT. Zaopatrzenie w jod w Polsce niemowlęta do szóstego miesiąca życia (Iodine supply in Poland - infants up to 6 months old). Endokrynol Ped. 2019;61-70.

32. Błazewicz A, Makarewicz A, Korona-Glowniak I, Dolliver W, Kocjan R. Iodine in autism spectrum disorders. J Trace Elem Med Biol. 2016;34:32-7.

33. Valentín-Blasini L, Mauldin JP, Maple D, Blount BC. Analysis of perchlorate in human urine using ion chromatography and electrospray tandem mass spectrometry. Anal Chem. 2005;77(8): 2475-81.

34. Anastassiades M, Kolberg DI, Eichhorn E, Wachtler A-K, Benkenstein A, Zechmann S, et al. Quick Method for the Analysis of Numerous Highly Polar Pesticides in Food Involving Extraction with Acidified Methanol and LC-MS/MS Measurement. European Union Reference Laboratory for pesticides requiring Single Residue Methods (EURL-SRM). Stuttgart, Germany: EURL-SRM; 2013. 